\title{
Part-Time Early Retirement in Europe
}

\author{
by Lei Delsen*
}

\section{Introduction}

Due to demographic developments, the costs of voluntary early retirement in Europe will escalate in the future. Moreover full early retirement has become increasingly popular and its financing could, therefore, become problematic in the 1990's. The aging of the European labour force will not only result in a smaller body of workers that must finance the early retirement benefits of a growing body of early leavers. It will also become increasingly difficult to recruit younger workers from the labour market to replace the early leavers. Bottlenecks in the provision of personnel will occur. Not only for financial and organisational reasons, but also for socio-psychological reasons, a phased retirement is to be preferred above an abrupt and forced retirement from (ending of) working life. In addition, the EC-initiatives to reach a more smooth and humane transition from working life to retirement render necessary a rethinking of the retirement situation (Commission of the European Communities, 1986). A way to achieve this phased retirement is the introduction of a system of voluntary partial early retirement.

This paper gives a comparative analysis of the national, legal voluntary part-time early retirement schemes in Western Europe. First, voluntary part-time early retirement is defined. Next, the rationale behind part-time early retirement is explored. The main characteristics and results of the national part-time early retirement schemes already being applied are analysed. The factors that further and impede it are reviewed. The consequences of part-time early retirement for employees, employers and the government are examined. Special attention is paid to the business-economic consequences of phased retirement: personnel planning; performance of older workers; organisational consequences and personnel costs. The paper concludes with some policy proposals for improvement of the existing schemes and future prospects.

\section{Definition}

Phased retirement means, in general, that the transition from the active phase of professional commitments to the pension phase, takes place over a longer period in the framework of a gradual - step by step or continuous - reduction of professional activities, the main part of which consists of a reduction in working time (Stitzel, 1987, p. 11). In relation to gradual retirement, the following five possibilities may be identified:

* Department of Applied Economics, Nijmegen University, Thomas van Aquinostraat 6, 6525 GD Nijmegen. This paper is based on a report on experiences with part-time early retirement in Europe (Delsen, 1989a). An earlier version of this paper was presented at the inaugural conference "Employment in Europe in the 1990s; the chances for a new deal" of the European Association of Labour Economists in Turin, September 1989. 
- working time reduction with the attached right to part-time early retirement benefit begins before the age of retirement laid down by the full early retirement regulation;

- gradual retirement is allowed before the earliest pension date, but to compensate, one has to work for the same length of time after the normal age of retirement in order to receive a full pension;

- gradual retirement is possible from the normal pension age onwards;

- gradual retirement is allowed only within the framework of an early retirement scheme. The existing full early retirement scheme is replaced by a part-time early retirement scheme;

- full and part-time early retirement schemes exist side by side.

Part-time voluntary early retirement is a form of gradual retirement from the labour process involving a transformation of a full-time job into a part-time job (or the hours worked for the part-time job are reduced) with the loss of wage related to the reduced working hours being replaced by a voluntary early retirement benefit.

\section{Applied part-time early retirement schemes}

The number of European countries that have introduced a part-time early retirement scheme is limited. Moreover the majority of these schemes are recent innovations. Parttime early retirement may be applied on national, sectoral or enterprise level. This paper is limited to the analysis of existing national schemes. ${ }^{1}$ With regard to the national, legal parttime early retirement schemes already applied in Europe, a distinction can be made between schemes with an obligatory replacement condition and schemes without a replacement condition. The Swedish, Danish and Finnish schemes have no replacement obligation. The schemes in France, the United Kingdom and Spain all have a replacement condition. The system applied in the Federal Republic of Germany does not have a replacement obligation, however refunding of premiums will only take place when replacement has been carried out.

Part-time early retirement schemes provide older employees with increased freedom of choice and flexibility with regard to when and how they prefer to retire. This gradual transition to complete retirement contributes to the humanisation of work. These schemes may also improve the employment situation by sharing available jobs between a larger number of people as a means of reducing unemployment. The schemes with a replacement condition emphasise the latter.

With the exception of the German system, in all the other countries under review, the part-time early retirement system exists parallel to a full early retirement system. In the case of Germany, the existing, full early retirement scheme was replaced by the part-time early retirement scheme. ${ }^{2}$

The Swedish partial pension scheme is financed by a pay-roll tax. Under the German scheme, the costs are also borne by the employer. However, in the event that the resulting

1 The introduction of (partial) early retirement regulations by European governments often resulted in a reduction of participation in or the closing of phased enterprise pension programmes (Swank, 1982, pp. 22-23; Casey, 1987, p. 358).

${ }^{2}$ In France the full early retirement scheme under the solidarity contracts was abolished in 1983 in order to promote the partial early retirement option, which is much cheaper from the point of view of the public purse (Laczko, 1986, p. 225). In the United Kingdom, in 1986, the part-time Job Release Scheme was brought to a halt, while the full Job Release Scheme continued to function. 
vacant part-time jobs are refilled by someone registered as unemployed, full refunding of the extra costs takes place. The other European, national, part-time early retirement schemes are state financed. Contrary to the full early retirement schemes, none of the national schemes gives employees the right to part-time early retirement. Partial early retirement has to take place as a result of agreement between employee and employer.

Tables 1 and 2 summarise the main characteristics and results of the national part-time early retirement schemes.

\section{Sweden}

An important conclusion to be drawn from the experiences with part-time early retirement in Europe is that until now, only the Swedish system has proved to be successful. The partial pension was proposed by the Union of Metalworkers in 1973, and the system was introduced in 1976. Until 1981, the number of people opting for part-time early retirement was high; after 1981, the number of new entrants fell. By 1986, the number of partial pensions awarded (8.300) was $55 \%$ below the number reached in $1979(18.243)$. This can be ascribed to the cutback in the replacement rate afforded by the partial retirement benefit and the growing pressure on Swedish industry to restructure. In 1987 the level of the income compensation was raised to its former level. Following this, the number of new entrants again increased, rising to 14.700 in 1987 . In 1988 there were 14.000 new entrants.

A condition sine qua non for the success of part-time early retirement systems is an adequate supply of part-time work for older employees. The Swedish practice shows that it is possible to create suitable part-time jobs for older employees. Employer cooperation in arranging part-time schedules has helped make the partial pension a reality for many Swedish employees. In a study of 28 workplaces, only 3 out of 400 applications for part-time employment had been blocked (Crona, 1981, p. 8). The principal factor determining variations between proportions of partial pensioners in different enterprises was the degree to which the firms needed to reduce personnel. Firms which needed to shed manpower were more likely to encourage partial retirement and less likely to replace partial pensioners (Crona, 1980; Blyton,1984, pp. 78-79; Laczko, 1988, p. 155). There were relatively few problems with the implementation of reduced hours. Research findings available on partial pension point to a freedom of choice on the individual's own terms. But there are also signs of the active participation of trade unions and employers in connection with retirement in certain cases (Fellenius, 1984, p. 11).

An important feature of the Swedish scheme is that the partial pension is counted as pensionable income, thus making it particularly attractive. Part-time early retirement offers the opportunity to reduce the professional burden of older workers before the generally agreed age limit for retirement. This may help to prevent the "overloading" of older workers. This is a step forward as far as the increased humanisation of work is concerned. The partial pension has indeed had a positive effect on its recipients. Partial retirement has achieved many of its intended results in relation to elderly workers (Crona, 1980; Fellenius, 1984 , p. 20): a spreading of the age of retirement; a partial increase in freedom of choice regarding to retirement; positive effects on the ability of elderly persons to remain in employment and improvement of the living conditions of partial pensioners. Their health also seems to improve and absenteeism declines. These facts account for a feeling among employers that partial pensioners produce more per hour than full-time workers. They are also less likely than full-time workers of the same age to become disabled or unemployed (Crona, 1980; Ginsburg, 1985, p. 40). The Swedish government may, therefore, also benefit from the system. 


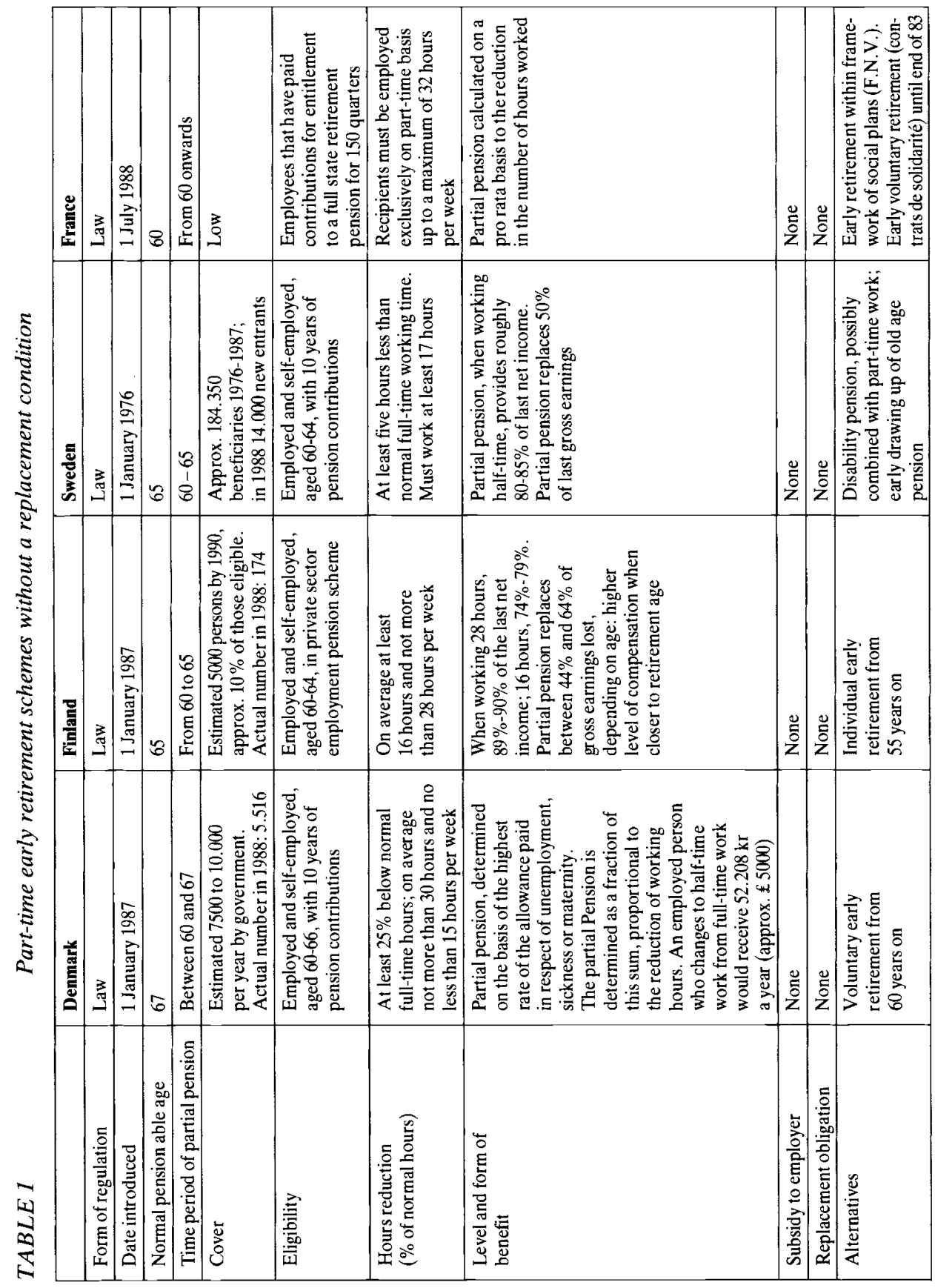




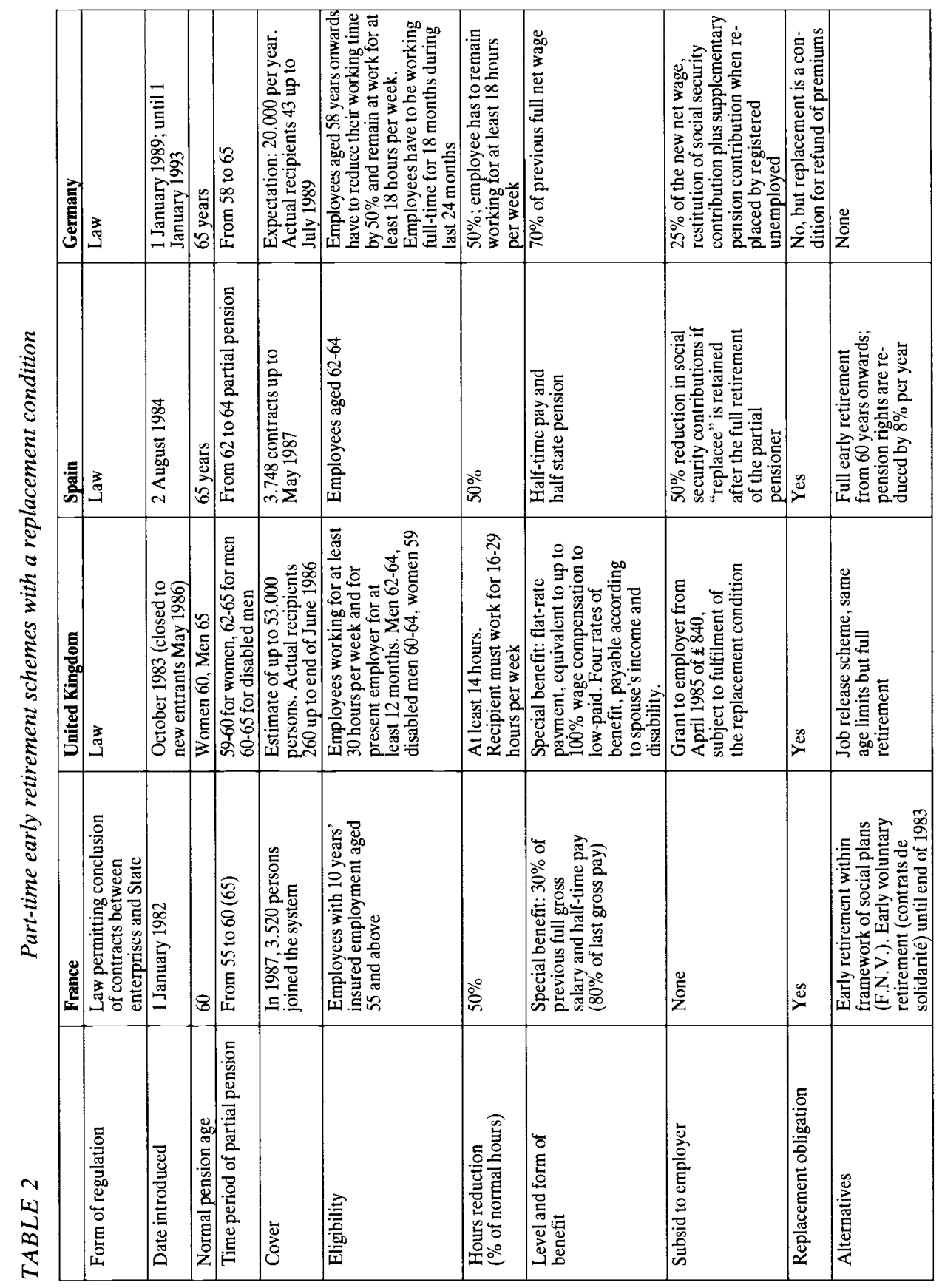




\section{Other European countries}

The national part-time early retirement schemes in the other European countries have, so far, failed. The schemes in France, the United Kindom and Spain, introduced in 1982, 1983 and 1984 respectively, have a replacement condition. The Danish and Finnish systems were introduced in 1987 and the German system in 1989. The actual taking hold of the schemes in these countries is much lower than was estimated. Their failure may attributed to the unfavourable labour market and the increase in full early retirement. When the schemes were being introduced in Denmark and Finland, there was great pressure on older workers to retire early as a result of the recession. The experience of France and the United Kingdom suggests that it is difficult to promote part-time early retirement when there are greater advantages for both employer and employee in choosing full early retirement (Laczko, 1986, pp. 223-224; Laczko, 1988, pp. 161-162; Jacobs, 1988, pp. 2-4; Casey, 1987, p. 358). Employers regard part-time early retirement as more cumbersome than full early retirement, partly because of the technical diffculty in adapting jobs to part-time work and partly because of the cost of adapting such jobs and the administrative burden involved. The main factor affecting employers' policies seems to be that they can make greater salary savings and do more to rejuvenate and restructure their workforce by using full rather than partial early retirement.

The replacement conditions in France, ${ }^{3}$ Spain and the United Kingdom act as a disincentive to employers to supply part-time jobs. This was a particular problem in the United Kingdom as employers were required to recruit two unemployed people for two partial retirees rather than recruit one full-time replacement worker. Employers also have the problem of recruiting suitable part-time replacements from among the unemployed. Yet there is not much incentive for the unemployed to fill part-time vacancies, since the wages obtained from part-time work are likely, except for the very young living at home or for married women, to be less than the benefits payable if they remain jobless. Moreover, if the replacement rate afforded by the full early retirement benefits differs only a little from part-time early retirement, as in France and Sweden (between 1981 and 1987), or the working time reduction results in a loss of their future pension entitlements (as in the United Kingdom in the case of occupational pension schemes), there is little financial incentive to choose partial early retirement rather than full early retirement for either employers or employees. The replacement condition restricts demand for part-time early retirement of workers in other ways. In particular, those working in declining sectors of the economy, where there is less likelihood of the replacement condition being fulfilled, are not in the position to choose part-time early retirement as an alternative to full early retirement or redundancy. Furthermore, a social consensus on the advantages of part-time early retirement is a condition for

${ }^{3}$ The French Government issued regulations on 15 April 1987 introducing a system of half-time early retirement in cases of planned reductions in the workforce (without replacement condition). Employees aged 56 years 2 months or - exceptionally - 55 years who have worked full-time for the previous 12 months may benefit from a scheme financed through the National Employment Fund (FNE), provided that they agree to work half-time as a result of the economic difficulties of their company. They will receive half-time pay plus an extra $30 \%$ of their final pay up to the social security ceiling (currently $9630 \mathrm{~F}$, or $£ 970$ a month), as well as $25 \%$ on any pay above that, up to a maximum of four times the ceiling. The company contributes towards the cost at a rate equal to $6 \%$ of the employee's daily pay multiplied by the total number of days that the FNE will be financing the employee's early retirement top-up (EIRR, 161, June 1987, p. 4). The utilisation of this scheme is low (Jacobs, 1988). 
success of such schemes, as the Danish practice shows. The Danish unions, as well as the social democrats, oppose the part-time early retirement scheme (Jacobs, 1988, p. 3; Petersen, 1988, pp. 18-19). Another obstacle to promoting part-time early retirement, and perhaps a more enduring one, could be the current low status of much part-time employment and its association, among older men, with employment of women (Laczko, 1986, p. 225). It is still too early to evaluate the German system. The results, however, may be disappointing; employers as well as unions think the system is unattractive (EIRR, 178 November, 1988, p. 4).

Under certain conditions the French law of 5 January 1988 allows employees voluntarily to go part-time for the final stages of their working life - probably with the same employer - while at the same time receiving a partial pension calculated on a pro rata basis to the reduction in the number of hours worked. The full pension is paid once the employee ceases work altogether. This scheme, which took effect on 1 July 1988, requires the employee to fulfil three conditions: to be aged at least 60 ; to have paid the requisite number of years' contributions for entitlement to a full state retirement pension (that is, 150 quarters); and to be employed exclusively part-time up to a maximum of 32 hours a week, probably with the same employer. Employees on phased retirement do not acquire any other supplementary right associated with full retirement. The succes of this scheme remains to be seen. At the moment, only an estimated $2.2 \%$ of enterprises have reorganised working time in favour of workers approaching retirement. Amongst such enterprises, $67 \%$ grant extra holidays, $24 \%$ grant a reduction in the working day or week and $21 \%$ have introduced some form of phased retirement (these different methods may, of course, co-exist) (EIRR, 172, May, 1988, p. 15).

Although the adoption of the various European part-time early retirement schemes is low, workers are interested in such schemes. Studies suggest that highly qualified workers and persons in a position of responsibility find it difficult or even impossible to adapt to working part-time (Laczko, 1988, p. 162). However, there are indications of potential great interest in phased retirement within workers' households themselves. For example Drèze $(1985$, p. 30) quotes results from a large German survey of workers in 1979 in which $70 \%$ of the respondents were in favour of "progressive retirement". In addition to this, a sample survey in nine EC-countries indicates a clear interest in progressive retirement among employed persons in general $(72 \%)$ and among the public $(71 \%)$ (Commission of the European Community, 1978). Interest in progressive retirement has been confirmed by the Swedish experience. Moreover its appeal has spread from blue collar to white collar workers. It should be recalled that this scheme of partial retirement was introduced in Sweden in order to improve the quality of life and not for reasons of employment (Aström, 1977). Several recent surveys among the elderly in Germany show that more than half of the respondents want gradual retirement (cf. Schüle, 1987, p. 166). Research in the United Kingdom shows that, in general, women $(62 \%)$ were more in favour of gradual retirement than men $(50 \%)$. The proportions who said they would personally like to retire in this way were somewhat lower: women $44 \%$; men $38 \%$. Those in non-manual occupations were more likely to personally prefer gradual retirement than those in manual occupations (Ritchie and Barrowclough, 1983, pp. 93-96). Recent research in Ireland indicates that $44 \%$ of the respondents would have preferred some type of phased retirement, while only $4 \%$ have actually retired on a gradual basis (Whelan and Whelan, 1988, p. 50). Recent research among civil servants of the Ministry of Internal Affairs in The Netherlands shows that half of the respondents are interested in part-time early retirement. 


\section{Rationale for part-time early retirement}

\subsection{Costs of early retirement}

Part of the rationale for part-time early retirement is that it is cheaper than full early retirement, given that partial rather than full pensions are paid. The introduction of parttime early retirement is in line with the present policy of reducing government spending and taxes, advocated by monetarism and supply side economic theory. The experiences in Sweden show that the government may benefit from the introduction of part-time early retirement. The net costs are lower because part-time early leavers remain working, produce goods and services and pay taxes and social security premiums. Moreover parttime early retirement limits the number of full invalidity pensions and the number of unemployment benefits and, hence, government spending. The disappearance, however, of full-time jobs, may signify a reduction of tax revenues (Fellenius, 1984, pp. 13, 19-20). The German system of part-time work for elderly workers is also expected to have a net advantage for the government. The costs of the part-time early retirement scheme are compensated for by a reduction in spending on unemployment. Moreover, more pension contributions are received and less pensions paid. In the Netherlands, sectoral part-time early retirement schemes have recently been introduced in the metal sector and for employees of architects' bureaus. These recent developments in the Netherlands illustrate the role part-time early retirement may play in reducing total costs of early retirement (Delsen, 1989a, pp. 5659). The introduction of part-time early retirement may also reduce the costs of early retirement for enterprises (see 7. Business-economic aspects).

\subsection{Humanisation of work}

The welfare rationale behind introducing a phased retirement provision is that it is said to avoid the danger of the individual experiencing a "pension shock" resulting from an abrupt transition from full-time work to complete retirement. Yet, whilst this may be a major justification for the introduction of phased retirement measures, several investigations suggest that the existence of a "pension shock" cannot be proved empirically (Casey and Bruche, 1983, p. 25; Stitzel, 1985, p. 119; Schüle, 1987, p. 61; Whelan and Whelan, 1988, pp. 35-36).

Increasingly, however, older workers are leaving the labour force involuntarily because of unemployment or sickness (Laczko et al., 1988). Where early retirement is involuntary and sudden, it can be a particularly stressful event, given that in most industrialised countries a strong work ethic prevails and status is closely associated with occupation. Phased retirement, in such circumstances, might reduce the likelihood of this occuring by allowing the older worker to make a gradual transition from work to retirement. Another advantage of part-time retirement is that it enables those concerned to prepare themselves for eventual retirement whilst continuing in their occupation and maintaining contacts with their collegues. It enables older workers to stay in the labour force and earn part of their income rather than relying on transfer payments (Clutterbuck, 1974; Laczko, 1988, p. 153). In Sweden part-time early retirement is used to avoid dismissals (Fellenius, 1984, p. 13).

In addition to early retirement, disability is also one of the causes of early termination of an active career. Among the present disabled many would be willing and able to accept a (part-time) job if a suitable job was available (Jacobs, 1988, p. 9; Delsen, 1989b). An advantage of part-time early retirement is that it reduces the professional burden of older 
workers at an earlier stage. This will prevent the overloading of older workers, and means a step forward regarding the increased humanisation of work. It enables older workers in poor health to reduce their working hours but remain in the labour force (Clutterbuck, 1974; Laczko, 1988, p. 153). Some cases of premature termination of work due to disability will no longer occur if the person concerned is offered a part-time job. Disability prevention is not only in the interest of disabled workers, but in the interest of employers and governments as well (Delsen, 1987). The experiences in Sweden show that the partial pension has a restraining effect on the growth in the number of full disability pensions awarded (Fellenius, 1984, p. 13).

The introduction of part-time early retirement is an institutional way to promote parttime work. It may contribute to the humanisation of work in the sense that it enables the individual worker to bring into agreement its preferences concerning the number of hours to work with the factual hours worked (Delsen, 1988).

\subsection{Unemployment}

According to Drèze, part-time work stands out as the most disappointing approach to work sharing, in the sense that its potential to alleviate unemployment, which could be substantial, has not been exploited at all in the recent European experience. This is all the more disappointing since part-time early retirement would seem much more natural and appealing than abrupt early retirement; given the substantial measure of success met by early retirement programmes and the interest, expressed by workers, in gradual retirement, it is doubly disappointing to observe the total failure of the timid attempts in that direction. Although efforts to promote part-time work are bound to be slow in producing their effects, because they call for substantial reorganisation of work, such efforts are worth undertaking in the long-term perspective (Drèze, 1985, p. 40; 1986, p. 597).

Part-time retirement will only contribute to the fight against unemployment as far as it does not take the place of full early retirement. That is why it is often suggested that the direct effect of part-time early retirement on unemployment will be modest. However, the impact of a part-time early retirement scheme on unemployment depends to a large extent on its design. ${ }^{4}$ Up to now part-time employment in Europe has been almost exclusively a female phenomenon, concentrated in lower functions within the service sector. Most of these are dead-end jobs. The introduction of a part-time early retirement scheme will imply ar breakthrough of part-time work to other economic sectors and other (higher) functions and part-time work for men will be increasingly accepted. Around two thirds of the Swedish partial pensioners are men. Its appeal has spread from blue collar to white collar workers. In $1982,40 \%$ of all newly-granted partial pensions in Sweden went to individuals with a higher income (above 5 times the Swedish base amount) (Ginsburg, 1985, p. 39; Laczko, 1988, p. 158). In Denmark around half of the partial pensioners were employed in agri-

4 On 1 July 1989, an experimental part-time early retirement scheme was introduced for civil servants in the Netherlands. Its aim is to improve the employment situation. In principle every civil servant is offered the possibility of part-time early retirement one year before reaching the normal full early retirement age. Working time is reduced by $50 \% ; 80 \%$ of the loss of wage is compensated for by the voluntary early retirement benefit. To participate, the civil servant has to work for at least 16 hours per week. The scheme will cost 25.000 guilders per participant. It is expected that half of the 1900 potential participants will actually choose this option. A similar scheme exists for teachers (see note 5). 
culture, compared to around $20 \%$ in industry and around $30 \%$ in the service sector. Owing to this, the redistribution of labour by part-time early retirement may be considerable.

\section{Business-economic aspects}

Although phased retirement may be functional for older workers and advantageous for governments, its introduction will only take place if it means the creation of business-economic advantages that correspond to the interests of industry. In order to establish the significance of part-time early retirement for industry, four areas are of importance: personnel planning, performance of older workers, organisational consequences and personnel costs.

\subsection{Personnel planning}

In practice, full early retirement is often used to get rid of redundant personnel. Full early retirement, however, is a rather inflexible instrument for personnel management. Even at this stage, in certain parts of the labour market problems are occuring regarding recruitment of personnel to replace the early retirees. As for full early retirement, part-time early retirement is also utilised - as the Swedish practice shows - to get rid of redundant older workers. Moreover, the disadvantages of full early retirement can be avoided. Full early retirement signifies the loss of certain valuable skills and know-how attached to the older workers. Part-time early retirement schemes may be designed to overcome the problems of productivity and/or investment losses due to older workers leaving the firm. Where a job may be shared between a younger and an older worker, not only will the employer be able to retain the human capital resources of the older worker and to benefit longer from the experience and know-how of those concerned, but the system may also provide - as practice shows - a particularly cost-effective way of imparting a specific skill endowment to young workers (Hart, 1984, p. 79). Part-time early retirement may therefore contribute to the planning of personnel, i.e. assure the continuity of personel. European experiences show that phased retirement is advantageous from the company's point of view because it allows a smooth taking over of the retiree's job (Clutterbuck, 1974). It allows the organisation to train the successor to share the responsibilities of the job with the older worker while the transition takes place, thus aiding the learning process (IDS, 1981, p. 75). Recent research in the United Kingdom shows that difficulties in recruiting and training are the major rationale behind firms offering part-time work. It is a way of gaining access to a wider labour market of relevantly skilled workers (Meager and Buchan, 1988, pp. 23-24). In the Netherlands, the recently introduced part-time early retirement schemes in the metal sector and for employees of architects' bureaus illustrate the importance of retaining the know-how and experience of older workers as a motive for the introduction of part-time early retirement (Delsen, 1989a, pp. 56-59).

The decision about full early retirement lies with the employee. He decides whether or not to retire early and the moment of full retirement. As a result, uncertainty about the exact moment that certain functions will become vacant increases, and, thus, personnel planning is hampered. As indicated in paragraph 3, none of the European part-time early retirement schemes provide a right to phased retirement. It has to take place after agreement between employee and employer has been reached. This facilitates the planning of personnel. Also the reduction of unpredictable sick-leaves resulting from part-time retirement facilitates the personnel planning. 


\subsection{Performance of older workers}

Beliefs that older employers have poorer health, lower productivity, rigid behaviour, inability to learn new skills and high accident rates may influence the employer to treat older employees differently than younger employees (Ford and Fottler, 1985, p. 154). Full early retirement is often applied by employers because of a supposed general reduction in the job performance of the elderly. Studies show, however, that only small changes in an individual's ability to perform at the workplace are associated with age. Older workers are often more productive than younger ones. The variation of productivity within an age group is usually larger than the productivity differences between cohorts. The introduction of new technologies may imply that some portion of the older workers human capital has become obsolete. This vintage effect eliminates much of the value of the experience of the senior worker relative to younger employees. The combination of a decrease in learning ability and obsolescence of human capital implies that the training costs are likely to be higher for older workers, particularly for those with a lower than average education and skills. However, evidence from a study suggests that age, by itself, is not a reliable or useful criterion for determining the suitability of workers for training. Even if the individual's capacity curve starts to decline with age, work performance can be extended through job redesign or worker retraining (cf. Clark, Kreps, Sprengler, 1978, pp. 927-928; Stitzel, 1985, p. 120; Stitzel 1987, pp. 47, 153 and 168; Schüle, 1987, p. 60). The introduction of part-time early retirement is an instrument for lengthening working life. If working life is expanded then the retraining of older workers will become more attractive, because investment in human capital can be amortised over a longer period.

Part-time early retirement influences the performance of older workers in two ways: the performance per unit of time changes and the reduced working hours have to be compensated for by another worker, e.g. through twin-jobs. The sinergy effects and/or coordination problems given rise to, may have a positive or a negative impact on performance. Literature shows that the productivity of part-time workers is, in general, higher than that of full-time workers (Delson, 1986). The experience with part-time early retirement in Sweden confirms this: older workers are more productive and absent less frequently when working part-time (Fellenius, 1984, p. 12; Crona, 1980; Ginsburg, 1985, p. 40). The experiences with company phased retirement programmes in Germany, France and the United Kingdom also show a considerable improvement in the health situation of the workers and a decrease in absenteeism (Schüle, 1987, pp. 162-163, 176; Teriet, 1978, p. 369; IDS, 1981, p. 75). Other research in Europe shows that the benefits of phased retirement for employers include increased employee morale and productivity, together with reduced absenteeism and disability claims (Schwank, 1982).

\subsection{Organisational consequences}

Working time reduction within the phased retirement process will often compel the introduction of a part-time work system. The arguments of employers against part-time early retirement are, in principle, identical to those against part-time work : a job cannot be "split", organisational problems, lack of acceptance by managers, impossibility of finding a "twin". However practice shows that many more functions can be filled by part-time workers than is now the case, and that in individual cases, flexible "splitting" possibilities can be found, even for jobs that are considered "unsplittable" (e.g. management functions) (Stitzel, 1985, p. 120; Delsen, 1986, p. 175; Schüle, 1987, p. 173; Strümpel, 1988, p. 69). 
The experience in Sweden also shows that, in principle, older workers working part-time can be deployed efficiently (Crona, 1980). The Swedish partial pension plan demonstrates that reductions in hours can be implemented in a wider variety of ways and in more occupations than conventional wisdom suggests, especially when management is cooperative (Ginsburg, 1985, p. 40).

In literature, it is often stated that the functions suitable for execution on a part-time basis are characterised by short, easy controllable, simple and systematic pursuits (Delsen, 1986). The fact that short, cyclical, "greatly subdivided" and standardised tasks can, in the framework of function "splitting", be made accessible for phased retirement, is of quantitative importance, because it means that in highly industrialised economies, a large number of the jobs satisfy the work organisational conditions for "splitting". Even more important is the qualitative aspect that, through this, phased retirement can be brought about for those workers for whom a reduction in the burden of work in the last phase of their working life is very desirable, especially if their tasks are characterised by heavy physical demands (Stitzel, 1987, pp. 123-124).

The supposition that the organisational problems are difficult to control is a considerable impediment to the introduction of phased retirement (Stitzel, 1987, p. 102). The experience with part-time early retirement in Sweden shows that the reduction in working time caused few problems. Some organisational changes were necessary due to partial retirement. Some firms indicated as problems the fact that extra administrative costs and extra personnel planning were necessary. On the other hand, there was a reduction in absenteeism and a higher productivity rate. Employers acted in a cooperation fashion. Rarely were individual applications for partial retirement blocked by an employer (Crona, 1981, p. 8). The experiences with enterprise-based part-time early retirement schemes in Germany also show that, where managers had a positive attitude towards part-time work, no "principle organisational difficulties" occurred. The increase in organisational effort and the costs of personnel and equipment for the job is compensated for by greater flexibility and a lower rate of absenteeism.

\subsection{Personnel costs}

As indicated in the previous paragraphs, part-time early retirement reduces the costs of personnel because partial, instead of full pensions, are paid. Moreover, the introduction of part-time early retirement limits the growth in the number of full disability pensions. Firms utilise part-time early retirement to get rid of and to rejuvenate their personnel. All three factors contribute to a reduction in the costs of personnel. ${ }^{5}$

\footnotetext{
${ }^{5}$ The government may also use part-time early retirement to reduce the costs of personnel. In the Netherlands, in December 1987, a part-time early retirement scheme was succesfully introduced for the personnel of primary and secondary schools. Its aims are to reduce unemployment among teachers, to reduce the wage costs and to rejuvenate the personnel. From the age of 55 onwards, teachers can retire partially $(50 \%)$. They receive a benefit of $80 \%$ of the income loss due to the working time reduction (the full early retirement age is 57 years). The scheme has a replacement condition: the vacant jobs have to be refilled by starting teachers aged 30 or younger or by re-enterees. The rate of adoption is high: 63\% (Delsen, 1989a; pp. 55-56). A similar scheme was introduced on 1 July 1989 for civil servants in the Netherlands (see note 4).
} 
The mystery is, then, why there has been a general reluctance by firms and employees to participate in partial retirement schemes despite evidence of worker support for such initiatives. According to Hart, one explanation may lie in the fact that fixed employment costs, with respect both to specific investments and social security contributions, are likely to be higher under partial early retirement with part-time job replacement than full early retirement with full-time job replacement. Marginal employment subsidies for the fixed costs may prove to be a particularly effective means of improving the rate of adoption of such schemes (Hart, 1987, p. 247).

The method of financing the part-time early retirement scheme is of importance in this matter. The Swedish partial pension system is financed by a pay-roll tax. For employers, this entails an increase in costs. This may result in a reserve, and a decrease in demand for labour. Another method of financing is chosen by the German system. Under the condition of replacement, the extra premiums paid by the employer are fully refunded by the State. For employers, such a system does not have to result in extra costs.

Progressive retirement raises specific problems: calculation of what previous "full time" meant in the case of some occupations ; calculation of complex work schedules; holidays; the difficulty of creating enough part-time jobs. Yet it enables undertakings to benefit longer from the experience of older workers. If it is properly co-ordinated with the progressive entry of young people into employment, it may help to improve their training by integrating them better into the day-to-day reality of working life (Cuvillier, 1984, p. 96). As already indicated, part-time early retirement is applied by employers to avoid productivity and investment losses due to older workers leaving the firm. It may also be used as a way to train the successors. Even when training is not the primary rationale behind the programme, many firms see it as a beneficial byproduct of the phasing process (Swank, 1982, p. 17; IDS, 1981, p. 75).

The quantification of the costs and benefits of part-time work is only possible for each enterprise separately. Even then not all effects can be taken into account. Notably the benefits are difficult to quantify. Several cases show, however, that the experiences with part-time work are positive and that the benefits outweight the costs (Delsen, 1986; Bierig, $1980 ;$ Nerb, 1986). The benefits gained by retaining the skills of older workers have been and will continue to be greater than the costs, especially as the supply of new entrants into the workforce diminishes. In many cases, the costs for higher average salaries caused by a longer tenured workforce can be more than offset by reduced recruitment and training costs of new employees, plus reduced retirement benefit costs (Ford and Fottler, 1985, pp. 155-156).

To conclude, in principle there are no business or economic obstacles to the introduction of part-time early retirement: the additional costs can be counterbalanced by the extra benefits.

\section{Outlook}

Regarding the European labour supply, some important changes are taking place. The aging of the labour force will cause bottlenecks in the provision of personnel. Even now shortages already exist for certain parts of the labour market, e.g. more highly educated personnel. The aging of the labour force will demand that in the future, older workers remain in service for as long as and as efficiently as possible and with the requisite level of 
productivity. Part-time work can offer, in many cases, a good solution to the problems associated with the functioning of older workers. Almost all of the projected increase in the general participation rate on the labour market in the OECD-area can be accounted for by female prime-age workers (OECD, 1987, pp. 54-62). It is expected, even, that the welleducated women will do for the 1985-2010 post-industrial economies what the peasants did for the 1950-1975 factory boom (The Economist, August 1986, p. 12). The sharp increase in the participation rate of the female labour would seem likely to imply some reorganisation of working time, notably an increase in part-time employment. Women who work parttime are usually rather overqualified for the jobs they perform and thus can be trained relatively easily for a more demanding job. The organisation will benefit from the creation of a reserve of potential managers at a time when most organisations will experience a shortage (Demeninth-De Jongh, 1989). Due to the aging of the labour force, the number of disabled persons will increase. For the majority of the disabled workers, part-time is the only way to participate in the labour process. The increased supply of part-time labour offered by the partially disabled will make part-time jobs more desirable, and will help to avoid future unemployment (Delsen, 1989b). Promotion of part-time work is important, because the number of part-time jobs is stagnating, and the unemployment rate seems to have stabilised at a high level. The introduction of part-time early retirement is an institutional way to promote part-time work. The introduction of such a scheme will imply the introduction of part-time work in male professions and functions where this is still rare, and this will contribute to the acceptance of part-time work for men. The introduction of part-time early retirement will therefore imply a breakthrough of part-time employment to other sectors of industry and to other (higher) functions. Through this, a contribution - by way of a redistribution of work - will be made to the expansion of employment opportunities and to the process of emancipation. In addition the number of full early retirement and full disability benefits will decrease, as will the total costs of early retirement.

From the experience with part-time early retirement in Europe, it may be concluded that not only is it advantageous for employees, but for employers and governments too. The potential benefit, for workers, organisations and society will more than offset the difficulties and costs involved. Another conclusion that can be drawn from the European experience with part-time early retirement is that the labour market situation is a major factor determining the failure or success of such schemes. At a time when unemployment is rising steeply and both undertakings and the public sector are being forced to rationalise and cut down on personnel, it becomes increasingly difficult to gain welfare benefits, such as freedom of choice and job opportunities for the elderly (Fellenius, 1984, p. 22). It seems that the restructuring process of industries is presently coming to an end. In several branches, labour shortages are occuring due to the use of full early retirement. Full early retirement results in the loss of the know-how and experience of the early leavers. An important condition for the success of a part-time early retirement scheme is an adequate supply of part-time jobs. Sectoral part-time early retirement schemes have been recently introduced in the Netherlands in the metal industry and architectural sectors. These schemes were initiated by employers, and their main aim is to reduce the total early retirement costs and to retain the knowledge and experience of older workers. Offering part-time work is a way of gaining access to a wider labour market of relevantly skilled workers, thus avoiding recruitment and training-related difficulties. The present economic growth will moreover contribute to the success of part-time early retirement in the sense that it is in the 
interest of the employer to replace the partial leavers - irrespective of the existence of a replacement condition - and so contribute to the redistribution of work and increase employment opportunities for the unemployed.

There are a number of reasons why a national, legal part-time early retirement scheme is to be preferred over a sectoral or enterprise scheme; for instance an early retirement scheme in the form of an outline law would lay down broad lines within the limits of which the social partners could manœuvre by way of collective bargaining agreements tailored to the specific circumstances in a certain sector of industry. In view of the general - social as well as economic-interest of such a regulation, a broad level of accessibility which would be facilitated by a national scheme, is desirable. From the viewpoint of legal equality, it is also desirable that all older workers - disregarding "accidental" employment in a certain sector of industry or by a certain employer - are offered a partial early retirement opportunity by means of a national scheme. Moreover, this scheme will be independent of the business cycle situation.

\section{TABLE 3:}

Aims and design of part-time early retirement schemes

\begin{tabular}{llllll}
\hline $\begin{array}{l}\text { primary } \\
\text { aim }\end{array}$ & $\begin{array}{l}\text { part-time early } \\
\text { retirement before } \\
\text { full early } \\
\text { retirement }\end{array}$ & $\begin{array}{l}\text { part-time early } \\
\text { retirement } \\
\text { replaces full } \\
\text { early retirement }\end{array}$ & $\begin{array}{l}\text { part-time early } \\
\text { retirement } \\
\text { next to full early } \\
\text { retirement }\end{array}$ & $\begin{array}{l}\text { state } \\
\text { financed }\end{array}$ & $\begin{array}{l}\text { replace- } \\
\text { ment } \\
\text { obligation }\end{array}$ \\
\hline $\begin{array}{l}\text { reduction of } \\
\text { unemployment }\end{array}$ & $\times$ & & $\times$ & $\times^{*}$ \\
$\begin{array}{l}\text { reduction of } \\
\text { early retirement } \\
\text { costs }\end{array}$ & $\times$ & $\times$ & \\
$\begin{array}{l}\text { humanisation } \\
\text { hef work }\end{array}$ & $\times$ & $\times$ & $\times$ & \\
\hline
\end{tabular}

${ }^{*}$ Supplemented by a right to partial early retirement for the employee.

The design of such a national part-time early retirement scheme is strongly determined by its aim (see table 3). From the point of view of reduction in unemployment, a part-time early retirement scheme placed before the full early retirement scheme is to be preferred. Such a system was recently introduced, by the Dutch Ministry of Internal Affairs, for civil servants. State financing and the introduction of a replacement condition are also desirable 
in that case, as well as a right to partial early retirement. When the aim stresses the reduction of early retirement costs, then the replacement of the full early retirement scheme by a state financed part-time early retirement scheme is to be preferred. ${ }^{6}$ Such a system was recently introduced in the Federal Republic of Germany. When priority is given to the humanisation of work, a state financed part-time early retirement scheme, combined with a part-time early retirement scheme in addition to the full early retirement scheme, supplemented by a right to part-time early retirement and a replacement condition, is more appropriate.

Another factor of importance when designing a national legal part-time early retirement scheme is the financial consequences. For individuals and firms the financial arrangements made during the phasing period, as well as the financial security offered with early retirement, will be crucial in determining the level of interest in the overall success of phased retirement (Blyton, 1982, p. 36). To be successfull, the part-time early retirement system must safeguard employees against financial losses which are too great. This can be achieved by a sufficiently high income replacement rate and avoidance of the loss of future pension entitlements due to the working time reduction, as in West Germany and Sweden. Financing by a pay-roll tax, as in the Swedish case, is not desirable because of its negative impact on the demand for labour. The increase in costs generated by this method of financing the scheme, may, moreover, result in a reserve. A state financed part-time early retirement scheme is to be preferred. Savings on unemployment and disability benefits may be used to finance it.

A last factor to be mentioned for guaranteeing the success of a part-time early retirement scheme, is a social consensus on the advantages of part-time early retirement. European employers' organisations are in favour of more part-time work. Part-time work is considered as a means of increasing flexibility and reducing labour costs through more efficient assignment and use of manpower. However, contrary to the theoretical preferences, practice shows that employers are often reluctant to introduce and expand part-time work. Employers overestimate the disadvantages and underestimate the advantages of part-time work. The extent of part-time work largely reflects the preferences of workers, accommodated by employers, rather than the other way around, while employers are the most important factor behind the growth of temporary work. However, temporary labour contracts may very well be counter-productive, while, on average, the experiences with parttime work are positive (Delsen, 1989c). Empirical evidence indicates there is a considerable untapped potential for part-time jobs in Europe (Nerb, 1986). Employers' arguments against part-time early retirement are, in principle, identical to those against part-time work. Until now, employers are the main impediment to the success of such systems, and are motivated by the supposed negative organisational consequences. As this paper demonstrates, part-time early retirement is not only in the interest of employees, it is also to their advantage. Employers should adapt to part-time work, because it can be flexible enough to deal with changes in the labour force over the next ten years, and it can help avoid bottlenecks in the provision of personnel.

\footnotetext{
${ }^{6}$ A full closing of the early retirement option is of course the best guarantee of the reduction of early retirement costs. But in the light of high unemployment rates, this is neither desirable nor feasible.
} 
Practice shows that unions' attitudes towards part-time work tend to be somewhat defensive or even hostile. Trade unions are afraid of labour market segmentation, and this is why they oppose part-time and temporary labour contracts (Delsen, 1988; KravaritouManitakis, 1988, pp. 46-47). Related to the precariousness and insecurity of part-time employment, recent research shows that part-time jobs are not necessarily less secure than full-time jobs (OECD, 1986, pp. 19-29; OECD, 1987, p. 35; Büchtemann and Schupp, 1988, pp. 27-31). Moreover, part of this labour market segmentation may be attributed to the trade union policy towards flexible labour contracts. Rejection of flexible labour relations by the trade unions results in a weak labour market position for these groups. Here a vicious circle exists. Rejection by the trade union does not stimulate personnel on flexible labour contracts to become active trade union members. They remain outside the trade unions. The fact that trade unions have hardly any members among categories of workers with a weak labour market position results in trade unions not using their powers to bargain for them. Until now, priority has been given to the male, full-time worker. If, however, the trade unions want to live up to their claim to represent the interests of large categories of workers, they cannot deny the differences in interest between these categories. In previous paragraphs it is shown that part-time early retirement is functional for older workers and that in Europe there is a clear interest in progressive retirement. Trade unions, as democratic institutions, should overcome their distrust of this type of employment and turn their energies to defending the rights of temporary workers and to promoting part-time work. (Delsen, 1988). Moreover, the promotion of part-time employment by means of part-time early retirement may be used as a policy to organise the new (female) entrants to the labour market. 


\section{REFERENCES}

ASTRÖM, L. A. (1977) Gradual transition from full-time work to retirement, with income deriving in part from work and in part from a reduced pension, Report IX, XIXth General Assembly of the International Social Security Association, Madrid, 4-14 October, 1977, pp. 1-12.

BIERIG, G. (1980) Teilzeitarbeit. Siemens-Untersuchung, Der Arbeitgeber, Nr. 21/32, pp. 1257-1260.

BLYTON, P. (1982) Phasing in early retirement, Personnel Management, November, pp. $32-36$.

BLYTON, P. (1984) Partial Retirement: Some Insights from the Swedish Partial Pension Scheme, Ageing and Society, 4, pp. $69-83$.

BÜCHTEMANN, C.F. and SCHUPP, J. (1988) Socio-economic aspects of part-time employment in the Federal Republic of Germany, Research Unit Labour Market and Employment, Wissenschaftszentrum Berlin für Sozialforschung, Berlin.

CASEY, B. and BRUCHE, G. (1983) Work or Retirement, Gower, Aldershot.

CASEY, B. (1987) Early retirement: The problems of instrument substitution and cost shifting and their implications for restructuring the process of retirement, International Social Security Review, Nr. 4, pp. 343-360.

CLUTTERBUCK, D. (1974) Helping employees phase smoothly into retirement, International Management, April, pp. 18-20.

Commission of the European Communities (1978) The attitude of the working population to retirement, Brussels (doc V/ 547 / 78-EN).

Commission of the European Communities (1986) Report from the Commission to the Council on the Application of the Council Recommendation of 20 December 1982 on the Principles of a Community Policy with Regard to Retirement Age, Brussels, (COM (86) 365 Final).

CRONA, G. (1980) Partial Retirement in Sweden : Developments and Experiences, Ageing and Work, Spring, pp. 113-120.

CRONA, G. (1981) Partial Early Retirement in Sweden, paper presented at the XII International Congress of Gerontology, Hamburg, July 12-17.

CUVILLIER, R. (1984) The Reduction of Working Time, International Labour Office, Geneva.

DELSEN, L. (1986) Deeltijdarbeid: Mythe en Realiteit. Een Literatuurstudie, Presses Interuniversitaires Européennes, Maastricht.

DELSEN L. (1987) Disability Prevention on Firm Level, Research Memorandum 8705, Institute of Economics, University of Nijmegen.

DELSEN, L. (1988) Flexible labour contracts and inflexible trade unions, Working Paper 8807, Institute of Economics, University of Nijmegen.

DELSEN, L. (1989a) Deeltijd-VUT in Europa, OSA-Werkdocument, W60, Organisatie voor Strategisch Arbeidsmarktonderzoek, Den Haag.

DELSEN, L. (1989b) Improving the Employability of Disabled: A Practical Approach, International Journal for the Advancement of Counselling, Vol. 12, No. 2, pp. 125-135.

DELSEN, L. (1989c) Flexible labour contacts: the employers' perspective, Working Paper 8904 Institute of Economics, University of Nijmegen.

DRĖE, J. H. (1985) Work Sharing: Why? How? How not..., Economic Papers, No. 42, Commission of the European Communities, Brussels.

DRËE, J. H. (1986) Work-sharing: some theory and recent European experience, Economic Policy, October, pp. 562-619.

EIRR, European Industrial Relations Reviews, various issues.

ETUI, (1986), Flexibility of Working Time in Western Europe, European Trade Union Institute, Brussels. 
FELLENIUS, M. (1984) Partial Pension and Flexible Retirement Age - an Evaluation of the Swedish System, Swedish National Insurance Board, Stockholm.

FORD, C. and FOTTLER, M. D. (1985) Flexible retirement: slowing early retirement of productive older employees, Human Resource Planning, Vol. 8 (3), pp. 147-156.

GINSBURG, H. (1985) Flexible and partial retirement for Norwegian and Swedish workers, Monthly Labour Review, October, pp. 33-43.

HART, R. (1984) Shorter Working Time. A Dilemma for Collective Bargaining, Organisation for Economic Co-operation and Development, Paris.

HART, R. (1987) Working Time and Employment, Allen \& Unwin, Boston.

IDS (1981) Guide to Early Retirement, Incomes Data Services Ltd., London.

JACOBS, K. (1988) Teilrentenmodelle: Erfahrungen im In- und Ausland, Chronik 32, pp. 1-9.

KRAVARITOU-MANITAKIS, Y. (1988) New forms of Work. Labour law and social security aspects in the European Community, European Foundation for the Improvement of Living and Working Conditions, Dublin.

LACZKO, F. (1986) Phased Retirement in Western Europe, in : Ch. Phillipson et al. (Eds) Dependency and Interdependency in Old Age. Theoretical Perspectives and Policy Alternatives, Croom Helm, London.

LACZKO, F. (1988) Partial retirement: An alternative to early retirement? A comparison of phased retirement schemes in the United Kingdom, France and Scandinavia, International Social Security Review, No. 2, pp. 149-169.

LACZKO, F., DALE, A., ARBER, S. and GILBERT, G. N. (1988) Early retirement in a period of high unemployment, Journal of Social Policy, 17, pp. 313-333.

MEAGER, N. and BUCHAN, J. (1988) Job-sharing and job-splitting. Employer attitudes, Institute of Manpower Studies, Brigthon.

NERB, G. (1986) Employment problems: views of businessmen and the workforce, European Economy, no. 27, March, Commission of the European Communities, Brussels, pp. 5-10.

OECD (1986) Employment Outlook, Organisation for Economic Co-operation and Development, Paris.

OECD (1987) Employment Outlook, Organisation for Economic Co-operation and Development, Paris.

PETERSEN, J. H. (1988) The process of retirement in Denmark: trends, public discussion and institutional framework, Department of Economics, Odense University.

RITCHIE, J. and BARROWCLOUGH, R. (1983) Paying for equalisation. A survey of pension age preferences and their costs, Equal Opportunity Commission, Manchester.

SCHÜLE, U. (1987) Der gleitende Übergang in den Ruhestand als Instrument der Sozial- und Beschäftigungspolitik, Peter Lang, Frankfurt am Main.

STITZEL, M. (1985) Der gleitende Übergang in den Ruhestand - eine Pensionierungsform der Zukunft?, Mitteilungen aus der Arbeitsmarkt- und Berufsforschung, 18. Jg, Nr. 1, pp. 116-123.

STITZEL, M. (1987) Der gleitende Übergang in den Ruhestand. Interdisciplinäre Analyse einer alternativen Pensionierungsform, Campus Verlag, Frankfurt/New York.

STRÜMPEL, B. (1988) Arbeitsplätze sind teilbar, Der Spiegel, Nr. 30, Juli, pp. 68-69.

SWANK, C.S. (1982) Phased Retirement: The European Experience, National Council for Alternative Work Patterns, Washington.

TERIET, B. (1978) Gliding out : the European approach to retirement, Personnel Journal, July, pp. $368-370$.

The Economist, (1986) Why women get the jobs, August 23, pp. 11-12.

WHELAN, C. J. and WHELAN, B. J. (1988) The Transition to retirement, The Economic and Social Research Institue, Dublin. 